\title{
WORKING AND HEALTH CONDITIONS REPORTED BY INFORMAL COMMERCE WORKERS
}

\author{
Marcela Andrade Rios ${ }^{1}$, Adriana Alves Nery²
}

\footnotetext{
${ }^{1}$ Master in Nursing and Health. Professor of the Department of Education of the Universidade do Estado da Bahia. Guanambi, Bahia, Brazil. E-mail: marcelariosenf@gmail.com

${ }^{2}$ Ph.D. in Nursing Professor of the de Department of Health and of the Graduate Nursing and Health Program of the Universidade Estadual do Sudoeste da Bahia. Jequié, Bahia, Brazil. E-mail: aanery@gmail.com
}

\begin{abstract}
This study had the objective of describing the socio-demographic and professional profile, as well as the working and health conditions of informal workers in the commerce of the municipality of Jequié, Bahia. It is an epidemiological, cross-sectional study, conducted with 434 informal commerce workers at the Supply Center of Jequié. The data were analyzed descriptively using SPSS 15.0. It was found that $54.6 \%$ were male, mean age was 42.7 years, $50.9 \%$ were married/in a stable relationship, and $44.6 \%$ had an incomplete first grade as education. The professional aspects showed that the difficulty in finding employment was also the most reported reason that led individuals to the performance of informal activities (39.9\%). There was wide variation in average monthly income and working hours. According to the demand-control model analysis, most workers were defined as high-strain (28.1\%). Low back pain and hypertension were the most self-reported morbidities. One hundred and forty individuals (32.3\%) had suffered accidents. We suggest the strengthening of public occupational health policies aimed at informal workers.
\end{abstract}

DESCRIPTORS: Occupational health. Working conditions. Accidents, occupational. Commerce.

\section{CONDIÇÕES LABORAIS E DE SAÚDE REFERIDAS POR TRABALHADORES INFORMAIS DO COMÉRCIO}

RESUMO: Objetivou-se descrever o perfil sociodemográfico e ocupacional e as condições de trabalho e de saúde de trabalhadores informais do comércio do município de Jequié, Bahia. Estudo epidemiológico, de corte transversal, realizado com 434 trabalhadores informais do comércio do Centro de Abastecimento de Jequié. Os dados foram analisados descritivamente com a utilização do SPSS 15.0. Verificou-se que $54,6 \%$ dos trabalhadores eram do sexo masculino, idade média de 42,7 anos, 50,9\% casados/ união estável, e $44,6 \%$ com escolaridade de $1^{\circ}$ grau incompleto. Os aspectos ocupacionais mostraram que a dificuldade em conseguir emprego foi o motivo mais relatado que levou os indivíduos ao desenvolvimento de atividades informais $(39,9 \%)$. Houve variação na renda média mensal e na jornada de trabalho. De acordo com a análise do modelo demanda-controle, a maior parte dos trabalhadores foi enquadrada como alta exigência $(28,1 \%)$. A lombalgia e a hipertensão arterial foram as morbidades mais autorreferidas. Sofreram acidentes de trabalho 140 indivíduos (32,3\%). Sugere-se o fortalecimento das políticas públicas em saúde do trabalhador voltadas aos trabalhadores informais. DESCRITORES: Saúde do trabalhador. Condições de trabalho. Acidentes de trabalho. Comércio.

\section{CONDICIONES DE TRABAJO Y SE REFIERE A LOS TRABAJADORES DE LA SALUD EN EL COMERCIO INFORMAL}

RESUMEN: Objetivo describir las características sociodemográficas y laborales y las condiciones de trabajo y salud de los trabajadores del comercio informal en el municipio de Jequie, Bahia. Estudio epidemiológico, un estudio transversal llevó a cabo con 434 trabajadores informales Trade Center Supply Jequie. Los datos se analizaron de forma descriptiva con SPSS 15.0. Se encontró que 54,6\% eran varones, con una edad media 42,7 años, 50,9 \% estaban casadas, el 44,6 con 1\% de grado de la educación incompleta. Las características ocupacionales mostraron que la dificultad en conseguir un trabajo era la razón más informado que llevó a las personas al desarrollo de las actividades informales $(39,9 \%)$. Hubo variación en el ingreso promedio mensual y horas de trabajo. De acuerdo con el análisis del modelo de control de la demanda, la mayoría de los trabajadores se enmarcó como alta tensión (28,1 \%). El dolor lumbar y la hipertensión fueron los más morbilidades auto-reporte. Sufrieron accidentes en el trabajo 140 personas (32,3\%). Se sugiere fortalecer las políticas públicas en materia de salud ocupacional dirigidas a trabajadores informales.

DESCRIPTORES: Salud laboral. Condiciones de trabajo. Accidentes de trabajo. Chinches. 


\section{INTRODUCTION}

Employment has an important role in people's lives, because in addition to being a source of income, it is where the individual can feel useful, productive, and treasured, which elevates selfesteem. ${ }^{1}$ Favorable conditions for work processes that are linked to the use of workers' abilities and to work management have been identified as important requirements for work to become a source of pleasure, well-being, and health. ${ }^{2}$ In this sense, the type of organization and the type of work are fundamental to evaluating the processes of workers' health hazards. ${ }^{3}$

Beginning especially in the 1990s, the economic market in Brazil underwent significant changes. These changes resulted in a decrease in job openings and in types of employment contracts, which generated an expansion in the informal sector of the economy. This economic restructuring process was the result of the pressure generated by the economic opening of the country and by privatizations, which not only affected the level of employment, but also its quality, resulting in more flexible relationships and regimes. ${ }^{4}$

The informal sector is a grouping of low productivity activities constituted, in most cases, by workers who were not absorbed by the economy's formal sector. ${ }^{5}$ In this context, commerce that is carried out without legal protection for workers constitutes a large subdivision of the activities that make up the informal sector. It is an activity that tries to combat unemployment and low salaries, which are increasingly present in many countries.

The presence of a large number of people working in informal activities is noticeable in Brazilian cities. These are people who are distant from any formal employment relationships or workers' rights. The practice of informal commerce activities is included in this scope. The public space where these relationships can be detected to a high degree and variety is the street market. ${ }^{6}$

Although the reality of informal, precarious work is nothing new, few studies have approached the working and health conditions of informal merchants. Official statistics regarding workers' health in Brazil are limited because of the high level of underreporting of fatal and non-fatal work accidents, as well as of work-related diseases, especially for informal workers. ${ }^{7}$

Comprehending working conditions is a dialectical challenge, materially necessary to qualify the events that are hazardous to workers' health, characterizing them as elements that are part of the reproductive logic of the capitalist system. ${ }^{8}$

It is important to know the characteristics of the workers who are part of the informal sector of the economy, as well as the aspects related to the development of work, making it possible to know this part of the economy, which is still understudied in Brazil. It is also important to verify the occurrence of events and hazards in this part of the working population.

In the municipality of Jequié, state of Bahia, according to data from the Ministry of Work and Employment (Ministério do Trabalho e Emprego), as of the end of December 2010 there were 19,055 individuals in formal work positions. According to estimates from the same organization, that number represents less than half of the number of workers, ${ }^{9}$ confirming that many individuals are unemployed or involved in the informal sector.

A characteristic that is part of the spatial organization of Jequié is the existence of an emerging area where the main commercial and service activities are located, as well as the interurban transportation stations and the few lines of intraurban transportation. This area, known as the central area, or simply "the Center," is a result of the process of service and commerce centralization. ${ }^{10}$ In that context, this study has as its objective to describe the socio-demographic and employment profile, as well as working and health conditions, of informal workers in the commerce of the municipality of Jequié, state of Bahia.

\section{MATERIAL AND METHODS}

An epidemiological, cross-sectional study was carried out in the Vicente Grilo Supply Center (Centro de Abastecimento Vicente Grilo CAVG), Jequié, a medium-sized municipality in the countryside of the state of Bahia.

Most formal commercial enterprises, as well as the majority of informal workers, are located in the center of the city of Jequié. The CAVG is in this area, a place that gathers a large proportion of informal workers from different economic tiers. Its space is divided into pavilions, blocks, low-cost shopping centers, stands, and street vendors, with 1,404 commercial units, according to a general report made available by the CAVG's administration in 2012.

Because there is no estimation of the numbers of informal workers at the CAVG, a survey 
was carried out through all 1,404 commercial units that make up this important informal commercial space in the city. The survey result was 1,304 informal workers with ages starting at 14 who work off the books at the CAVG.

The study's population was comprised of workers who conduct professional activities in the commercial units registered at the CAVG, according to the following inclusion criteria: age equal to or over 14 years, and performance of professional activities at the CAVG that are not registered in professional employment papers for such activities. All subjects signed free and informed consent forms.

Sample calculus was performed through the software EpiInfo ${ }^{\circledR}$, version 6.04 (Center for Disease Control and Prevention, Atlanta, USA), reaching a total of 485 workers. The parameters that were used were: level of confidence of $95 \%$; margin of error of $2 \%$; proportion of incidence of work accidents of $6.5 \%$; ${ }^{11}$ and an addition of $20 \%$ to the resulting value, considering possible losses in the study. The study's subjects were chosen through systematic random sampling. The next survey on the list substituted workers who were not found after three visits in different days. Workers who refused to participate in the study were considered "losses."

Data were gathered between the months of January and March 2013 by applying a form with five blocks of variables: questions about sociodemographic characteristics (age, gender, marital status, education, income, skin color, place of birth); professional characteristics (type of goods sold, time at work, working hours, monthly income, property in goods sold, other paid activities, interest in leaving informality); working conditions (self-reported morbidity, search for health care services, and perception of health); and occurrence of work accidents in the last 12 months.

Psychosocial aspects of work were evaluated through the JCQ, an instrument developed by Karasek. ${ }^{12} \mathrm{JCQ}$ is based on the propositions of the demand-control model, which emphasizes control over one's own work and the psychological demands involved in its performance, such as the structuring characteristics of work organization. From this concept, a model for analysis of work situation, based on the simultaneous evaluation of control and demand levels, is proposed.

Therefore, the demand-control model establishes four work situations: low-strain work (which involves low psychological demand and high control); passive work (with low psychological demand and low control); active work (high psychological demand and high control); and high-strain work (high psychological demand and low control). This model supports the hypothesis that work performed in a high-strain situation represents the condition with the highest exposure and health risks. ${ }^{13}$

To build the database, the forms were typed into electronic spreadsheets in the software Microsoft Excel, and analyzed through the statistical software Statistical Package for The Social Sciences (SPSS); Version 15.0.

The study was sent for appreciation by the Research Ethics Committee of the State University of Southwest Bahia, Campus of Jequié, being approved under the CAAE number 04755112.3.0000.0055.

\section{RESULTS AND DISCUSSION}

\section{Socio-demographic and professional profile}

Of the 485 workers that were randomly drawn, $434(89.5 \%)$ accepted to be part of the study. The socio-demographic profile of these workers shows that $54.6 \%$ of them were males, with a minimum age of 14 and a maximum of 88 years, and a mean age of 42.7 years (standard deviation $=16.4$ ). There was a predominance of workers who were married/in a stable relationship $(50.9 \%)$, with education up to incomplete first grade $(44.6 \%)$ and self-reported as brown $(48.2 \%)$, as seen in table 1 . Most workers were born in the municipality of Jequié, where they work as street vendors $(64.7 \%)$.

Brazilian studies and those from other countries show low education for informal workers, in addition to a higher number of black and brown individuals in the informal market, which shows racial inequality.,14-18 Low education reinforces the hypothesis that many workers in informal commerce lack the necessary preparation to obtain formal employment; thus they search for this area in the informal commerce, which is defined as precarious work. Decent work, the opposite of precarious work, would be a fundamental condition to overcome poverty, to reduce social inequalities, to guarantee democratic governance and sustainable development. ${ }^{19}$ 
Table 1 - Distribution of socio-demographic characteristics of informal workers in the Vicente Grilo Supply Center. Jequié, Bahia, Brazil, 2013

\begin{tabular}{lrr}
\hline \multicolumn{1}{c}{ Socio-demographic Characteristics } & n & \multicolumn{1}{c}{$\%$} \\
\hline Gender & & \\
Male & 237 & 54,6 \\
Female & 197 & 45,4 \\
Age group (years) & & \\
Under 30 years & 60 & 13,8 \\
$30-60$ & 265 & 61,1 \\
60 and over & 109 & 25,1 \\
Marital status & & \\
Single & 175 & 40,4 \\
Married/stable relationship & 221 & 50,9 \\
Divorced/Separated & 21 & 4,8 \\
Widower & 16 & 3,7 \\
Not informed & 1 & 0,2 \\
Education & & \\
Illiterate & 62 & 14,3 \\
Incomplete elementary/middle school & 193 & 44,5 \\
Complete elementary/middle school & 30 & 6,9 \\
Incomplete high school & 43 & 9,9 \\
Complete high school & 98 & 22,6 \\
Incomplete third level education & 3 & 0,7 \\
Complete third level education & 5 & 1,1 \\
Ethnicity/color & & \\
White & 75 & 17,3 \\
Yellow & 11 & 2,5 \\
Brown & 209 & 48,2 \\
Native Indian & 31 & 7,1 \\
Black & 97 & 22,4 \\
Does not know/did not inform & 11 & 2,5 \\
\hline
\end{tabular}

As for characteristics related to work, the main goods sold were fruits and vegetables $(\mathrm{n}=171 ; 39.4 \%)$, followed by ready meals and beverages $(n=99 ; 22.8 \%)$, and meats and chicken $(n=54$; $12.4 \%)$. There was less frequency for reports of miscellaneous goods $(n=43 ; 9.9 \%)$, clothing $(n=34$; $7.8 \%)$, electronics $(\mathrm{n}=17 ; 3.9 \%)$, and medicinal herbs $(n=16 ; 3.7 \%)$. This demonstrates that most informal work in CAVG's commerce sector is directed at the street market, with fruit and vegetable stands, restaurants, and snack stands.

Difficulty in attaining formal employment was the most common reason that made individuals seek the informal commerce sector, as reported by 173 workers $(39.9 \%)$. Other reported reasons were: to follow family tradition ( $n=106 ; 24.4 \%)$; informal employment favors autonomy and freedom $(n=88 ; 20.3 \%)$; the possibility of higher income $(n=37 ; 8.5 \%)$; and other $(n=30 ; 6.9 \%)$.

After considering this result in conjunction with education level and ethnicity/color, it can be observed that these characteristics may affect the adoption of informality, since they obstruct access to the formal labor market. When discussing the reasons that lead workers to the informal sector, Chilean researchers, for example, inferred that many individuals are in this sector for various reasons, such as low education and few educational opportunities, racial and/or social segregation caused by physical limitations, or perhaps the simple reason that they have low-paying formal jobs, which makes them look into increasing their income through informality. ${ }^{20}$ Other reasons reported in the literature are linked to the excessive bureaucracy required to formalize their work when it has the potential to be legal, or the alternative of easy money, as is the case of drug distributors. ${ }^{21}$

This difficulty in entering the formal sector may also be explained through analysis of the workers' answers regarding their previous history of employment on the books. Among the workers researched, $286(61.9 \%)$ had never worked on the books in their entire working lives, and 165 individuals $(38.1 \%)$ reported having some kind of record of employment papers at some point in their lives.

When questioned about how long they had been conducting informal activities in commerce, reports varied from less than a year to up to 60 years, with an average of 11.7 years of work (standard deviation $=11.6$ ). The number of weekly working days varied from one to seven, with six being the most frequent, which was reported by 213 workers (42.6\%). Weekly working hours varied from five to 105 hours, with an average of 48.5 hours (standard deviation=21.5).

The average weekly working hours were higher than what is established for formal workers under the Brazilian Consolidation of Labor Laws (Consolidação de Leis Trabalhistas, [CLT]) where, according to the 1988 Federal Constitution (Constituição Federal de 1988), Article $7^{\text {th }}$, subparagraph XIII and CLT, Article 58, it is determined that working hours should not exceed eight daily hours and 44 weekly hours. ${ }^{22}$

The average monthly income received by the workers was $\mathrm{R} \$ 726.00$, with a large dispersion, which can be noticed in its standard deviation value of $R \$ 636.30$. Income reports varied from $\mathrm{R} \$ 50.00$ to $R \$ 6,000.00$. The highest average in- 
comes were found among workers who sold electronic products $(\mathrm{R} \$ 1,280.93)$, followed by meats and chicken $(\mathrm{R} \$ 1,053.45)$. On the other hand, those who sold ready meals and fruits and vegetables had the lowest average monthly incomes, $\mathrm{R} \$ 413.77$ and $\mathrm{R} \$ 420.00$, respectively. For $64.5 \%$ of workers, informal commerce constituted the families' main source of income.

It was noticed that activities more closely related to the street market, such as restaurants, snack stands, and fruit and vegetable stands had the lowest average incomes. These areas are precisely those with individuals who have the lowest education levels, and who generally come from rural areas. This appears to confirm the proposition that education level has an effect on income level in the labor market. ${ }^{4}$

\section{Profile of working conditions}

Working conditions obtained through the JCQ instrument are presented in table 2. We veri- fied that more than half of the workers agree or strongly agree that work in informal commerce is repetitive, requires creativity, and a high skill level; allows their own decision-making, development of special skills, and learning new things; that work is not excessive; that they have enough time to perform their work activities; and that the work is free of conflicting demands. This shows that workers have a certain control over their work, which is confirmed by the $45.6 \%$ frequency of workers with a high degree of control over their work, which involves abilities and the power to make decisions.

As for the physical aspects, most agreed that work demands high physical effort and quick and continuous physical activity, and that they have to keep their bodies in physically uncomfortable positions. As time goes on, such findings may lead workers to develop a process of physical deterioration. Almost all of them agree that their coworkers at the supply center are friendly, collaborative, and respectful.

Table 2 - Description of work content of informal merchants of Jequié, Bahia, Brazil, 2013

\begin{tabular}{|c|c|c|c|c|}
\hline \multirow{2}{*}{ Work content } & \multicolumn{2}{|c|}{ Disagree* } & \multicolumn{2}{|c|}{ Agree† } \\
\hline & $\mathbf{n}$ & $\%$ & $\mathrm{n}$ & $\%$ \\
\hline \multicolumn{5}{|l|}{ Control } \\
\hline Learn new things & 108 & 24.9 & 326 & 75.1 \\
\hline Repetitive work & 66 & 15.2 & 368 & 84.8 \\
\hline Requires creativity & 64 & 14.7 & 370 & 85.3 \\
\hline Requires high level of skill & 72 & 16.6 & 362 & 83.4 \\
\hline Enables learning new things & 208 & 47.9 & 226 & 52.1 \\
\hline Develop new abilities & 143 & 33 & 290 & 67 \\
\hline What they say is considered & 91 & 21 & 342 & 79 \\
\hline Allows own decision-making & 75 & 17.3 & 358 & 82.7 \\
\hline Decide how to do their own tasks & 314 & 72.4 & 120 & 27.6 \\
\hline \multicolumn{5}{|l|}{ Psychological demands } \\
\hline Hard work & 247 & 56.9 & 187 & 43.1 \\
\hline Accelerated work & 222 & 51.2 & 212 & 48.8 \\
\hline Work is not excessive & 186 & 42.9 & 248 & 57.1 \\
\hline Enough time & 50 & 11.5 & 383 & 88.5 \\
\hline Is free of conflicting demands & 190 & 43.8 & 244 & 56.2 \\
\hline \multicolumn{5}{|l|}{ Physical demands } \\
\hline High physical effort & 172 & 39.6 & 262 & 60.4 \\
\hline Quick and continuous physical activity & 208 & 47.9 & 226 & 52 \\
\hline Keep body in physically uncomfortable positions & 173 & 39.9 & 261 & 60.1 \\
\hline Keep head and arm in uncomfortable positions & 239 & 55.1 & 195 & 44.9 \\
\hline \multicolumn{5}{|l|}{ Social support from coworkers } \\
\hline Are friendly & 37 & 8.5 & 397 & 91.5 \\
\hline Are collaborative & 63 & 14.5 & 370 & 85.5 \\
\hline Respectful & 15 & 3.5 & 419 & 96.5 \\
\hline \multicolumn{5}{|l|}{ Other aspects } \\
\hline Salary (income) is adequate & 214 & 49.3 & 220 & 50.7 \\
\hline
\end{tabular}




\begin{tabular}{lcccc}
\hline \multirow{2}{*}{ Work content } & \multicolumn{2}{c}{ Disagree $^{*}$} & \multicolumn{2}{c}{ Agree† } \\
& $\mathbf{n}$ & \% & n & \% \\
\hline Work demanded more as years went on & 170 & 39.2 & 264 & 60.8 \\
Time pressure because of heavy load of work & 276 & 63.6 & 158 & 36.4 \\
Low work stability & 216 & 49.8 & 28 & 50.2 \\
Stifled by time pressure & 276 & 63.6 & 158 & 36.4 \\
\hline
\end{tabular}

* Disagree or strongly disagree; † Agree or strongly agree.

The JCQ answers were analyzed together and the dimensions of control over work and psychological demand were calculated, according to table 3 .

Table 3 - Distribution of categories from the demand-control model for informal workers in the commerce of Jequié, Bahia, Brazil, 2013

\begin{tabular}{lcc}
\hline Categories & n & $\%$ \\
\hline Control & & \\
High & 198 & 45.6 \\
Low & 236 & 54.4 \\
Psychological demand & & \\
$\quad$ High & 213 & 49.1 \\
Low & 221 & 50.9 \\
Demand-control model & & \\
$\quad$ Active work (high demand and low control) & 91 & 21 \\
Passive work (low demand and low control) & 114 & 26.3 \\
High-strain (high demand and low control) & 122 & 28.1 \\
Low-strain (low demand and high control) & 107 & 24.6 \\
\hline
\end{tabular}

It is possible to observe that there were no large variations found in the frequencies of the scales of the demand-control model. High-strain work was the most frequent, followed by passive work. Studies involving different professions note that workers under high strain present many different reactions to psychological tension (fatigue, anxiety, depression, and physical illnesses). If the length of exposure is short, the organism promptly recovers itself. If, on the contrary, it is long, damage is accumulated, which can lead the individual to develop psychological or physical illnesses., ${ }^{3,23-25}$

As for the low-demand conditions associated with low levels of control, they promote demotivation for work, leading to a decrease in learning and to gradual loss of previously acquired skills.

Low-strain work is, theoretically, ideal for health. At present, low demand in work environments mean an absence of excessive demand. Working on activities with low demand may put employment at risk and compromise the worker's social engagement. ${ }^{23-24}$ The worker feels a state of apathy, either because of the absence of significant challenges and permission for more energetic performance or because of the systematic rejection of his or her work initiatives. This is the second worst exposure for health.

Further on working conditions, 328 workers $(75.6 \%)$ perceived some risk factors for their health when performing their work at informal commerce and $24.4 \%$ answered that they felt no risk factors.

The perceptions of risk are directly linked to how individuals think, represent, classify, or analyze the many forms of threat that are present in their lives. They are constructed from experiences lived by social actors, based on the development of daily practices in the work environment, and more or less influenced by discourses and practices produced in the environment, as well as the political-ideological factors of the subjects who visualize, perceive, and receive information regarding what may constitute health risks in the work process. ${ }^{25}$ In this sense, what may represent health risks for one worker may not do the same for another person, because of the influence of aspects that are either cultural, social, economic, political, ideological, or symbolic that each worker possesses. It is important to note, in this aspect, that knowing the risks to which one is exposed may more effectively establish measures of prevention of diseases and hazards.

The risk factors most frequently reported by the 328 workers were related to biological aspects $(\mathrm{n}=177 ; 53.9 \%)$; followed by physical $(\mathrm{n}=98 ; 29.9 \%)$; chemical $(n=57 ; 17.4 \%)$, mechanic $(n=53 ; 16.1 \%)$; and ergonomic $(n=39 ; 11.9 \%)$. Some workers mentioned macro aspects that are risk factors for work performance, such as violence $(n=35 ; 10.7 \%)$, and macrostructural risks related to the organization and structure of the supply center $(n=36 ; 11 \%)$.

Among the interviewees, 384 workers $(88.5 \%)$ were satisfied or very satisfied with their work and $50(11.5 \%)$ were dissatisfied or very dissatisfied.

Concerning the events of work accidents in the last 12 months, 140 workers (32.3\%) suffered 
some kind of work accident when performing their activities in commerce. Of those, $114(81.4 \%)$ were typical accidents, especially due to knife cuts $(n=58 ; 50.9 \%)$ and lesions caused by some part of the stands' structure $(n=22 ; 19.3 \%)$. Twentysix events of commuting accidents $(18.6 \%)$ were reported. The main type reported by the workers was motorcycle accident $(n=16 ; 61.3 \%)$.

When informal workers suffer accidents and need health care or temporary health leave from their activities, their income often decreases, since there is no social protection for this, causing these workers to perform their work activities even under impaired health conditions.

Work accidents involving informal workers are not well documented in Brazil because a large part of available data refer to formal workers linked to Social Security (Previdência Social). ${ }^{7}$

\section{Health profile}

Among the workers, 315 (72.6\%) mentioned morbidities. Of those, 102 (23.5\%) reported having at least one diagnosis and $213(49.1 \%)$ reported having two or more. The most frequently reported diseases, according to Table 4, were low back pain $(35.9 \%)$ and arterial hypertension $(22.3 \%)$.

Table 4 - Morbidity reported by informal workers in the commerce of Jequié, Bahia, Brazil, 2013

\begin{tabular}{lcc}
\hline Self-reported pathologies & n & Prevalence \\
\hline Diabetes Mellitus & 27 & 6.2 \\
Arterial hypertension & 97 & 22.3 \\
Rhinitis/sinusitis & 58 & 13.4 \\
Heart disease & 19 & 4.4 \\
Gastritis & 58 & 13.4 \\
Urinary Infection & 34 & 7.8 \\
Asthma & 6 & 1.4 \\
Allergy & 100 & 23 \\
Low back pain & 156 & 35.9 \\
Varicose veins & 76 & 17.5 \\
Arthritis/rheumatism & 55 & 12.7 \\
Heart attack & 5 & 1.1 \\
Depression & 9 & 2.1 \\
Kidney disease & 24 & 5.5 \\
Other diseases & 67 & 15.4 \\
\hline
\end{tabular}

Sixty-four percent of workers rated their health as good or very good. This finding con- flicts with results found in studies where health perceptions of formal and informal workers were compared. ${ }^{15,26}$ However, it is necessary to take into consideration the fact that this study focused on a small part of the informal sector, vendors, which may influence results.

Regarding the search for health care services in the last 12 months, $63.8 \%$ of workers answered the question positively. Studies show that the search for health care services is higher among formal workers than among informal workers. ${ }^{15,26}$ The strengthening of the workers' health through primary care actions may be a route to decrease inequality in the search for health care services between formal and informal workers. ${ }^{27}$

\section{CONCLUSION}

The results found by this study showed a socio-demographic and occupational profile in which most informal workers were male, with ages from 14 through 88, with low levels of education, who self-reported as brown, as merchants of fruits and vegetables, with an average of 48.5 hours worked weekly, and who are part of the economy's informal sector due to difficulties in entering formal services. There was a large dispersion in relation to average monthly income in informal commerce.

High-strain work in the demand-control model was predominant in the study's population. It was observed that some of the workers reported not perceiving health risks in their work processes. A high incidence of work accidents was estimated, with a prevalence of those considered typical. Most workers reported some morbidity, especially arterial hypertension.

In this context, we call attention to the relevance of knowing which are the main events and hazards that affect the informal worker population, as well as their socio-demographic and professional characteristics, so that measures for promotion and prevention may be implemented through effective public policies.

Because of the fact that there is no national health information system that includes all events and hazards that affect informal workers, studies based on population and specific spaces are necessary to better understand the realities of the work and health conditions of the working population, who are frequently outside of official health and work statistics. 
Despite the limitations in this study, it allowed an instant view of the conclusion and exposition because of its cross-sectional nature. This, however, makes it impossible to understand the relationship among causes and effects in chronological terms. Nevertheless, it was relevant to evaluate the characteristics of informal commerce workers and their working conditions and to describe the work accidents they suffered, as well as self-reported morbidity.

\section{REFERENCES}

1. Campos Junior AP, Reis DS, Sato EG. A dor física relacionada ao ambiente ocupacional. Interdisciplinar: Rev Eletrônica da Univar. 2011 [acesso 2013 Ago 01]; 6: 22-6. Disponível em: http://www.univar.edu.br/revista/downloads/ dorfisicaambienterelacional.pdf

2. Delcor NS et al. Condições de trabalho e saúde dos professores da rede particular de ensino de Vitória da Conquista, Bahia, Brasil. Cad Saúde Pública. 2004 Jan-Fev; 20(1):187-96.

3. Ferreira DK, Bonfim C, Augusto LGS. Condições de trabalho e morbidade referida de policiais militares, Recife-PE, Brasil. Saúde Soc. 2012; 21(4):989-1000.

4. Costa MS. Trabalho informal: um problema estrutural básico no entendimento das desigualdades na sociedade brasileira. Cad CRH. 2010 Abr; 23(58):171-90.

5. Duailibe MD. A informalidade das relações de emprego e a atuação da inspeção do trabalho: uma análise para o Maranhão contemporâneo [dissertação]. São Luís (MA): Universidade Federal do Maranhão, Programa de Pós-Graduação em Políticas Públicas; 2010.

6. Alves AESA, Almeida JRM. Trabalho informal em tempos "globalizacionistas." Rev HISTEDBR Online. 2009 Mai [acesso 2013 Ago 08]; 9(Esp):238-50. Disponível em: http:/ / www.histedbr.fae.unicamp. br/revista/edicoes/33e/art15_33esp.pdf

7. Dias EC. Employment conditions and health inequities: a case study of Brazil. Cad Saúde Pública. 2011 Dez; 27(2):2452-60.

8. Lourenço EAS, Bertani IF. Saúde do trabalhador no SUS: desafios e perspectivas frente à precarização do trabalho. Rev Bras Saúde Ocup 2007; 32(115):121-34.

9. Ministério do Trabalho e Emprego (BR). Perfil do município. 2011 [acesso 2012 Dez 08]. Disponível em: http:// perfildomunicipio.caged.gov.br/ seleciona_uf_consulta.asp?uf $=$ ba

10. Torreão Sá TRB, Torreão Sá M. Os processos espaciais presentes no espaço urbano de Jequié Bahia. Estud Geográficos. 2004 Jun; 2(1):1-13.

11. Soares JFS. Incidência cumulativa anual de acidentes de trabalho não fatais - estimativas nacionais para o
Brasil [tese]. Salvador (BA): Universidade Federal da Bahia, Instituto de Saúde Coletiva; 2012.

12. Karasek RA. Job content questionnaire and user's guide. Lowell (U): University of Massachussets; 1985.

13. Gomes DJ, Araújo TM, Santos KOB. Condições de trabalho e de saúde de trabalhadores em saúde mental em Feira de Santana, Bahia. Rev Baiana Saúde Pública. 2011 Jan-Jun; 35(supl 1):211-30.

14. OIT. International Labour Organization; World Trade Organization. Globalization and informal jobs in developing countries. Geneva $(\mathrm{CH})$ : World Trade Organization; 2009.

15. Giatti L, Barreto SM. Situação do indivíduo no mercado de trabalho e iniqüidade em saúde no Brasil. Rev Saúde Pública. 2006 Fev; 40(1):99-106.

16. Kim MH, Kim CY, Park JK. Is precarious employment damaging to self-rated health? Results of propensity score matching methods, using longitudinal data in South Korea. Soc Sci Med 2008; 67(12):1982-94.

17. Quesnel-Vallée A, DeHaney S, Ciampi A. Temporary work and depressive symptoms: A propensity score analysis. Soc Sci Med. 2010; 70(12):1982-7.

18. Vasconcelos L. Realidade em preto e branco. Rev Desafios do Desenvolvimento. 2005 Mar [acesso 2012 Dez 08];17(2):1-8. Disponível em: http:/ /www. ipea.gov.br/desafios/index.php?option $=\mathrm{com}_{-}$ content\&view $=$ article\&id $=956$ : reportagens materias\&Itemid $=39$

19. Ministério do Trabalho e Empreo (BR). Plano Nacional de Emprego e Trabalho Decente. Brasília (DF): TEM; 2010.

20. Diaz EM, Guevara RC, Lizana J. Trabajo informal: motivos, bienestar subjetivo, salud, y felicidad en vendedores ambulantes. Psicol Estud. 2008 Out-Dez [acesso 2013 Mar 18]; 13(4):693-701. Disponível em: http://www.scielo.br/pdf/pe/v13n4/v13n4a07. pdf

21. Ocasio G. The formal problem of the informal economy. Caribbean Business. 2005 Jan; 33(2):12.

22. Martins SP. Direito do Trabalho. $14^{\mathrm{a}}$ ed. São Paulo (SP): Atlas; 2001.

23. Araújo TM, Graça CC, Araújo E. Estresse ocupacional e saúde: contribuições do modelo demanda-controle. Ciênc Saúde Coletiva. 2003; 8(4):991-1003.

24. Cardoso JP, Araújo TM, Carvalho FM, Oliveira NF, Reis EJFB. Aspectos psicossociais do trabalho e dor musculoesquelética em professores. Cad Saúde Pública. 2011 Ago; 27(8):1498-506.

25. Souza SF, Carvalho FM, Araújo TM, Porto LA. Fatores psicossociais do trabalho e transtornos mentais comuns em eletricitários. Rev Saúde Pública. 2010 Ago; 44(4):710-7.

26. Karasek R. Brisson C, Kawakami N, Houtman I, Bongers $\mathrm{P}$, Amick B. The Job content questionnaire (JCQ): an instrument for internationally comparative 
assessments of psycosocial job characteristics. J Occup Health Psycol. 1998 Oct; 3(4):322-55.

27. Miliquin IOC, Marín-León L, Monteiro MI, Correa Filho HR. Desigualdades no acesso e uso dos serviços de saúde entre trabalhadores informais e desempregados: análise da PNAD 2008, Brasil. Cad Saúde Pública. 2013 Jul; 29(7):1392-406. 